\title{
Bacteriological Evaluation of Meat Contact Surfaces at Egyptian Hypermarkets
}

\author{
Abdelrahman, H.A. a; Ismail, S.A.S. a; Harydi, A.M. b \\ a: Professor of Meat Hygiene / Faculty of Vet Med. Suez Canal \\ University / Egypt \\ b: Head of Microbiology Department /GOEIC-Food Safety lab. \\ / Port-said-Egypt
}

\begin{abstract}
A bacteriological survey was performed on different food contact surfaces in meat processing sectors at selected Egyptian hypermarkets. A total of $288 \mathrm{swab}$ samples from meat contact surfaces were obtained. Total aerobic count (TAC) and the presence of Staphylococcus aureus coliform, Escherichia coli and Salmonella spp. were determined. The mean values of TAC counts from working table, weighting scale, packing machine, vacuum machine, bone saw, meat mincer, worker hands, and cutting knife were $3.7,2.2,2.5,2.8,2.6,3.3,3.4$, and 2.5 $\log _{10} \mathrm{CFU} / \mathrm{cm}^{2}$ respectively. Staphylococcus aureus was detected in meat mincer worker hand and working tables while Coliform and Escherichia coli could be detected in bone saw cutting knife meat mincer and working tables. Salmonella species could not be detected in all examined swab samples. The results revealed that the examined meat contact surfaces were subjected to inadequate hygienic practices during processing and after day work.
\end{abstract}

\section{Introduction}

Inadequate hygienic practices within food processing plants lead to contaminate the produced products with a wide variety of pathogens and therefore may constitute a potential risk hazard to food safety (Metaxopoulos et al., 2003). It is difficult to eliminate completely the pathogenic microorganisms from raw materials and food processing environment because many pathogens are still attached and remain viable even after cleaning (Eisel et al., 1997; Fonnesbech-Vogel et al., 2001; Tompkin, 2002; Jessen and Lammert, 2003 and Deza et al., 2005). Food contact surfaces is any surface of equipment, utensil, knives, spoons, grater, scoops, spatulas, pots, mixing bowls, 
cutting boards, preparation boards, preparation tables, sinks, scales, mixers, kettles, slicer, food processor containers and wrappings that direct or indirect contact with food during processing, preparation, serving, holding and cooking processes (Holah and Kearney, 1992). Food borne pathogens cause economic losses as well as loss of productive man hours. Several food borne disease outbreaks have been reported throughout the world and the most frequently identified factors are crosscontamination, contaminated ingredients/equipments and poor personal hygiene. (Altekruse et al., 1998; Vought and Tautine, 1998; Shapiro et al., 1999)

The clean food contact surfaces are reducing the likelihood of transmission of food borne diseases (Cunningham et al., 2011)

It is still difficult to guarantee food safety from farm to fork in spite of many advances which occurred in food technology, (Duffy and Schaffner, 2002). In order to produce safe food the most efficient methods is to implement the Good Hygienic Practices and Good Manufacturing Practices as food programs Codex Alimentarius (1997) and
Eisel et al. (1997). The application of HACCP with the prerequisite points are efficient to prevent, reduced and even eliminate the causative agents responsible for food-borne outbreaks Ropkins and Beck (2003) and Reij et al. (2004).

Due to the nature of meat for its supporting the rapid growth and multiplication of a wide variety microorganism which contaminate it during processing. the Egyptian hypermarkets, specially meat sectors have started to implement the Good Manufacture and Hygienic practices in addition to HACCP that are compulsory in European Commission member countries.

Bacteriological contamination lead to spoilage of meat, decrease the shelf life and may cause 'health risk (Rao, 1992). The iplemintation of HACCP system in commercial food turf have faced specially to focus upon the microbial meat hazards. Therefore the GMP and the inforcement of strict sanitation standards in the meat processing sectors are necessary, and should include efficient cleaning of floors ,walls, knives , cutting tables, so that all meat contact surfaces are protected clean in order to minimize the 


\begin{abstract}
danger of microbial contamination (Butterworth and Heinemann, 2000).

In this study, the bacteriological profile of different food contact surfaces in meat processing sectors in a number of Egyptian hypermarkets were investigated, aimed at the consideration of consumer safety.
\end{abstract}

\section{Materials and methods}

A total number of 288 swabs 36 each of working table, weighting scale, packing machine, vacuum machine, bone saw, meat mincer, worker hands, and cutting knife were taken. For meat and meat products contact surfaces the swab technique was used in which a sterile template was used to sample $10 \mathrm{~cm}^{2}$ surface area (A.P.H.A, 1992)

Aerobic plate count: aerobic plate count was determined by plate count agar as described by (Bell, 1997).

Staphylococcus aureus: was determined by Baird Parker agar. A selective medium for the isolation and counting of coagulase positive staphylococci as described by (Bhandare et al., 2007). Escherichia coli: was determined by using Eosin Methylene Blue agar according to (Bhandare et al., 2007).

coliforms: coliforms were detected on VRBA agar according to (Bhandare et al., 2007).

Isolation of Salmonella: Was carried out according to (ISO 6579:2002)

Statistical software SPSS was carried out according to (SPSS Inc., 1992).

\section{Results and discussion}

The results showed in Table $1 \&$ figure 1 revealed that the mean values of TAC from working table, weighting scale, packing machine, vacuum machine, bone saw, meat mincer, worker hands, and cutting knife were 3.7 , $2.2,2.5,2.8,2.6,3.3,3.4$, and $2.5 \quad \log _{10} \mathrm{CFU} / \mathrm{cm}^{2}$ respectively. The highest counts were found in working table, followed by the workers hands and the meat mincer swabs samples. The lowest counts were found form the weighting scale followed by packing machine and cutting knife swabs samples.

The ANOVA results at $(\mathrm{P}<0.05)$ no significant difference between the bacterial counts for weighting scale, packing machine, vacuum machine, bone saw samples, and cutting knives. Meanwhile there was a 
significant

difference

between the bacterial counts for meat mincer, workers hand, working table swabs from one side and all the rest samples

The results given in Table (2) \& Fig (2) revealed that Staphylococcus aureus was detected in meat mincer worker hand and working tables while Coliform and Escherichia coli could be detected in bone saw cutting knife meat mincer and working tables. Meanwhile, Salmonella spp. could not be detected in all examined swab samples.

Escherichia coli is taken as indicator of faecal contamination of food. However, certain species are pathogenic and cause abdominal pain and diarrhea
(Ray, 2004 and Lawely et al., 2008).

Staphylococcal food poisoning arises from the consumption of food which containing the already performed Enterotoxin which is primarily a consequences of contamination by food handlers (Bryan, 1992; and Bergdoll, 1989).

The results obtained in this study revealed that working table, bone saw, meat mincer, worker hands, and cutting knife constitute a risks correlated with the insistences of critical organisms. These findings were nearly similar to the results mentioned by (Eisel et al., 1997; Gill and McGinnis 2004 and Temelli et al., 2006).

Table 1: Total aerobic counts $\log _{10} \mathrm{cfu} / / \mathrm{cm}^{2}$ in examined $S w a b$ samples $(n=288)$.

\begin{tabular}{|l|c|c|c|}
\hline $\begin{array}{c}\text { Swab site } \\
\text { 36 swab of each }\end{array}$ & $\begin{array}{c}\text { Mean } \pm \text { SD } \\
\log _{\mathbf{1 0}} \mathbf{c f u} / \mathbf{c m}^{2}\end{array}$ & Min. & Max. \\
\hline Bone saw & $2.6^{\mathrm{ab}} \pm 1.12$ & 1.0 & 4.2 \\
\hline Cutting knife & $2.5^{\mathrm{a}} \pm 1.07$ & 1.0 & 4.9 \\
\hline Meat mincer & $3.3^{\mathrm{bcd}} \pm 1.06$ & 1.0 & 4.8 \\
\hline Packing machine & $2.5^{\mathrm{a}} \pm 1.22$ & 1.0 & 5.1 \\
\hline Vacuum machine & $2.8^{\mathrm{abc}} \pm 0.98$ & 1.2 & 4.8 \\
\hline Workers hand & $3.4^{\mathrm{cd}} \pm 0.56$ & 2.4 & 4.5 \\
\hline Weighting scale & $2.2^{\mathrm{a}} \pm 0.86$ & 1.0 & 3.7 \\
\hline Working table & $3.7^{\mathrm{d}} \pm 1.47$ & 1.0 & 5.4 \\
\hline
\end{tabular}

$\mathrm{n}$ : number of analyzed samples

Means have different letter in the same column were significantly different $(\mathrm{P}<0.05)$. 


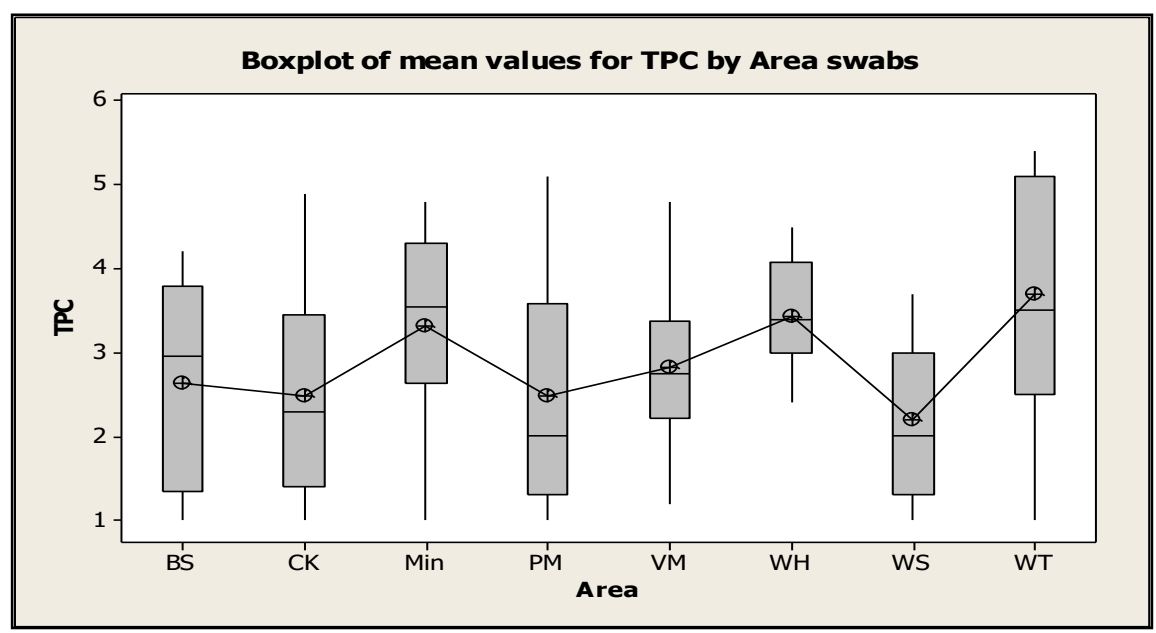

Figure 1: mean values of total aerobic counts $\log _{10} \mathrm{cfu} / \mathrm{cm}^{2}$ by area swabs $(n=288)$.

$\mathrm{BS}=$ Bone saw, $\mathrm{CK}=$ Cutting knife, Min=Meat mincer, $\mathrm{PM}=$ Packing machine, $\mathrm{VM}=$ Vacuum machine, $\mathrm{WH}=$ Workers hand, WS $=$ Weighting scale, $\mathrm{WT}=$ Working table

Table 2: Incidence of bacterial group in examined swab samples

$(n=288)$.

\begin{tabular}{|l|c|c|c|c|c|c|c|c|}
\hline $\begin{array}{c}\text { Swab site } \\
\text { 36 swab of } \\
\text { each }\end{array}$ & \multicolumn{2}{|c|}{$\begin{array}{c}\text { Staph. } \\
\text { aureus }\end{array}$} & \multicolumn{2}{|c|}{ Coliform } & \multicolumn{2}{c|}{ E. coli } & \multicolumn{2}{c|}{ Sal. spp. } \\
\hline Bone saw & 0 & $0.0 \%$ & 5 & $13.9 \%$ & 2 & $5.6 \%$ & 0 & $0.0 \%$ \\
\hline Cutting knife & 0 & $0.0 \%$ & 6 & $16.7 \%$ & 2 & $5.6 \%$ & 0 & $0.0 \%$ \\
\hline Meat mincer & 7 & $19.4 \%$ & 25 & $69.4 \%$ & 13 & $36.1 \%$ & 0 & $0.0 \%$ \\
\hline $\begin{array}{l}\text { Packing } \\
\text { machine }\end{array}$ & 0 & $0.0 \%$ & 0 & $0.0 \%$ & 0 & $0.0 \%$ & 0 & $0.0 \%$ \\
\hline $\begin{array}{l}\text { Vacuum } \\
\text { machine }\end{array}$ & 0 & $0.0 \%$ & 0 & $0.0 \%$ & 0 & $0.0 \%$ & 0 & $0.0 \%$ \\
\hline Workers hand & 21 & $58.3 \%$ & 0 & $0.0 \%$ & 0 & $0.0 \%$ & 0 & $0.0 \%$ \\
\hline $\begin{array}{l}\text { Weighting } \\
\text { scale }\end{array}$ & 0 & $0.0 \%$ & 0 & $0.0 \%$ & 0 & $0.0 \%$ & 0 & $0.0 \%$ \\
\hline Working table & 23 & $63.9 \%$ & 22 & $61.1 \%$ & 13 & $36.1 \%$ & 0 & $0.0 \%$ \\
\hline
\end{tabular}

n: number of swab samples 


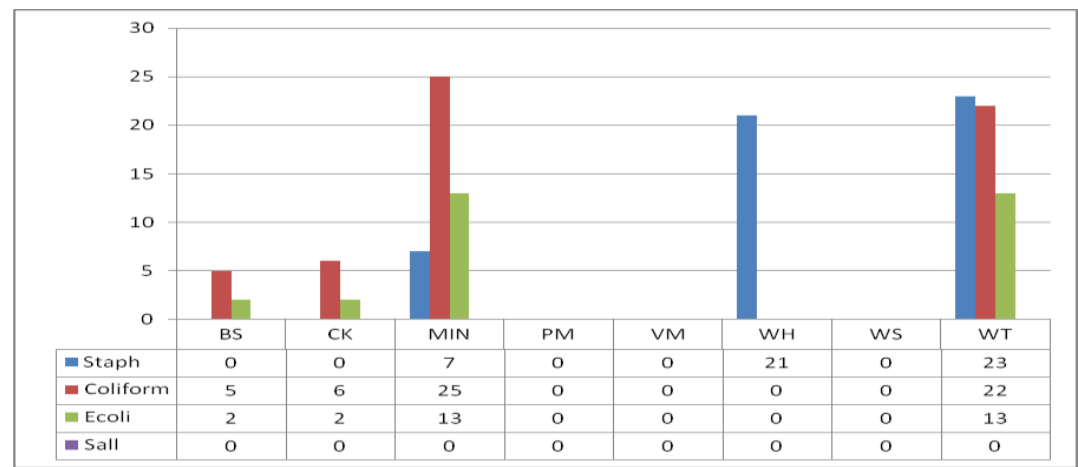

Figure 2: Incidence of bacterial group in examined swab samples $(n=288)$.

$\mathrm{BS}=$ Bone saw, $\mathrm{CK}=$ Cutting knife, $\mathrm{Min}=$ Meat mincer, $\mathrm{PM}=$ Packing machine, $\mathrm{VM}=$ Vacuum machine, $\mathrm{WH}=$ Workers hand, WS=Weighting scale, $\mathrm{WT}=$ Working table

\section{Conclusion}

The results obtained highlight the inadequacy of visual examination as a mean of assessing the cleanliness of food contact surfaces. Periodic swab sampling evaluation is important to check the effectiveness of the hygienic practices. Presence of coliforms, Escherichia coli and Staphylococcus aureus in samples underlines the need to establish and enforce bacteriological specifications for meat contact surfaces.

The production of high quality and safety meat products will be conceivable by application of Good Manufacturing and Hygienic practices with the implementation

$\mathrm{HACCP}$ system.

\section{Acknowledgements}

The authors are thankful to the Director, GOEIC - food safety lab. for providing necessary facilities for this research.

\section{References}

Altekruse S.F.; Timbo B.B.; Mowbray J.C.; Bean N.H. and Potter M.E. (1998): Cheese associated outbreaks of human illness in the United States, 1973 to 1992: sanitary manufacturing practices protect consumers. J Food Protect; 61:1405-1407.

A.P.H.A. (1992): Compendium of methods for the microbial examination of foods. 3rd rev. ed. C. Vanderzant and D.F. Splittstoesser, Washington, USA.

Bell, R. G. (1997): Distribution and sources of microbial contamination on beef carcasses. J Appl Microbiol. 82 (3): 292-300.

Bergdoll, M.S. (1989): Staphylococcus aureus. In: Foodborne Bacterial Pathogens 
- Marcel Dekker, Inc., New York, NY, USA.

Bhandare, S. G.; Sherikar, A. T.; Paturkar, A. M.; Waskar, V. S. and Zende, R. J. (2007): A comparison of microbial contamination on sheep/goat carcasses in a modern Indian abattoir and traditional meat shops. Food Control. 18 (7): 854-858.

Bryan, F.L. (1992): Hazard Analysis Critical Control Point Evaluations. Geneva: WHO.

\section{Butterworth-Heinemann}

(2000): The Science of Food. 4th rev. ed. Reed Educational and Professional Publishing Ltd., London, UK.

Codex Alimentarius (1997): Home page address: http://www.codexalimentarius. $\underline{\text { net }}$

\section{Cunningham,} A.E.; Rajagopal, R.; Lauer, J. and Allwood P. (2011): Assessment of hygienic quality of surfaces in retail food service establishments based on microbial counts and realtime detection of ATP. J Food Protect; 74: 686-690.

Deza, M.A.; Araujo, M. and Garrido, M.J. (2005): Inactivation of Escherichia coli, Listeria monocytogenes, Pseudomonas aeruginosa and Staphylococcus aureus on stainless steel and glass surfaces by neutral electrolysed water. Lett Appl Microbiol; 40: 341-346.
Duffy, S. and Schaffner, D.W.(2002): Quantitative risk assessment of microbial sampling effectiveness. Clin. Microbiol.

Newsletter 24(6):44-47.

Eisel, W.G.; Linton, R.H. and Muriana P.M. (1997): A survey of microbial levels for incoming raw beef, environmental sources and ground beef in a red meat processing plant. Food Microbiol; 14:273-282.

Fonnesbech-Vogel, B.; Jorgensen, L.V.; Ojeniyi，B.; Huss, H.H. and Gram, L. (2001): Diversity of Listeria monocytogenes isolates from cold smoked salmon produced in different smokehouses as assessed by random amplified polymorphic DNA analyses. Int J Food Microbiol; 65: 8392.

Gill, C.O. and Mcginnis, J.C. (2004): Microbiological conditions of air knives before and after maintenance at a beef packing plant. Meat Sci. 68:333-337

Holah, J.T. and Kearney, I.R. (1992): Introduction to biofilms in the food industry. In: Melo LF, Bott TR, Fletcher M, Capdeville B (Eds), Biofilms- Science and technology, Kluwer Academic press, Dordrecht, The Netherlands, pp 35-41.

International Organization for Standardization (2002): Horizontal method for the detection of Salmonella spp. 
ISO 6579:2002(E), Geneva, Switzerland

Jessen, B. and Lammert, L. (2003): Biofilm and disinfection in meat processing plants. Int Biodet Biodeg; 51: 265-269.

Lawely, R.; Curtis, L. and Davis J. (2008): Food safety hazard guide book. The royal society of chemistry, Cambridge, UK.

Metaxopoulos, J.; Kritikos, D. and Drosinos, E.H. (2003): Examination of microbiological parameters relevant to the implementation of GHP and HACCP system in Greek meat industry in the production of cooked sausages and cooked cured meat products. Food Control; 14: 323-332.

Rao, N.D.(1992):

The microbiology of sheep carcasses processed in a modern 1ndian abattoir. Meat Sci. 32:425-436.

Ray, B. (2004): Fundamental food microbiology, third edition CRC press LLC. Florida USA.

Reij, M.W. and Den Aantrekker, E.D. (2004): Europe risk analysis in microbiology task force. Int. J. Food Microbiol. 91:1-11.

Ropkins, K. and Beck, A.J. (2003): Using HACCP to control organic chemical hazards in food wholesale, distribution, storage and retail. Trends Food Sci. Technol. 14:374-389.

Shapiro, R.; Ackers, M.; Lance, S.; Rabbani, M.; Schaefer, L.; Daugherty, J.; Thelen, C. and Swerdlow, D. (1999): Salmonella thompson associated with improper handling of roast beef at a restaurant in Sioux Falls, South Dakota. J Food Protection; 62:118-122.

SPSS/PC+ (1992): Base System User's Guide. Version 5.0. SPSS Inc.; Chicago, IL, USA.

Temelli, S.; Dokuzlu, C. and Cem Sen, M.K. (2006): Determination of microbiological contamination sources during frozen snail meat processing stages. Food Control 17:22-29.

Tompkin, R.B. (2002): Control of Listeria monocytogenes in the food processing environment. J Food Prot; 65: 709-725.

Vought, K.J. and Tautine, S.R. (1998): Salmonella enteritidis contamination of ice cream associated with a 1994 multistate outbreak. J Food Protect; 61:5-10. 


\section{المدلذص النعربي}

\section{تقييم الجودة البكذريولوجية للاسطح الملامسة للحوم فى الاسدواق المركزية المبة لاسدر المدية}

' حسنى عبد اللطيف عبد الرحمن - ' سدعاد احمد سدليمان - الريمن محمد

'قسم الرقابة الصحبة علي اللحوم كلية الطب البيطري - جامعة قناة السوبيس

هريدى

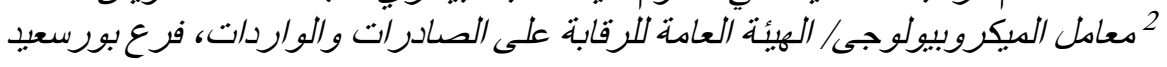

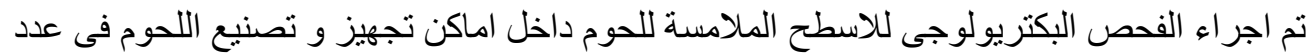

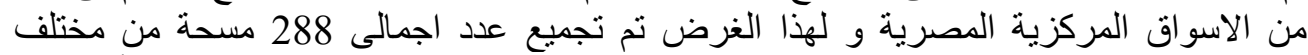

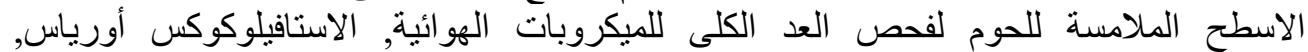

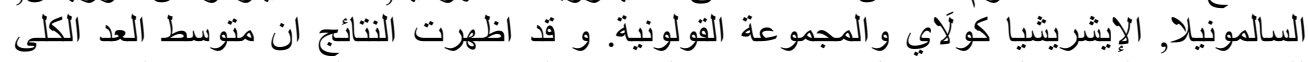

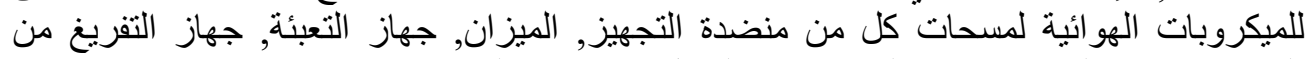
الضغط, منشار العظام, ماكينة الفرم, ايادى العمال و سكاكين القطع كان: 3.4.

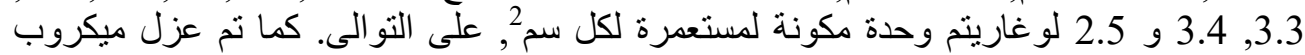

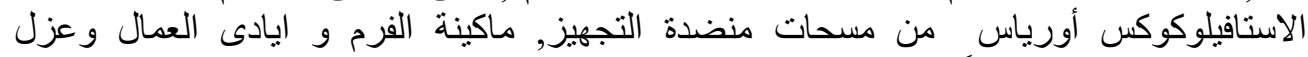

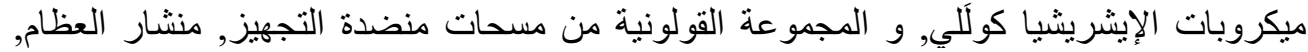

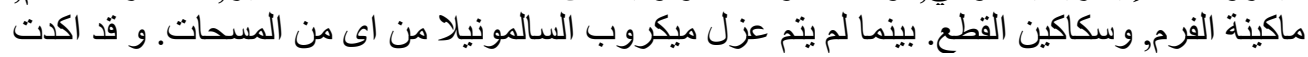

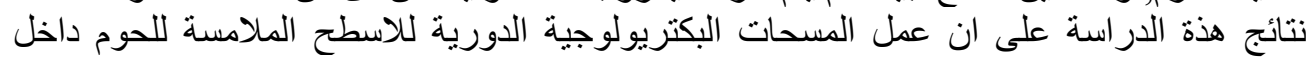

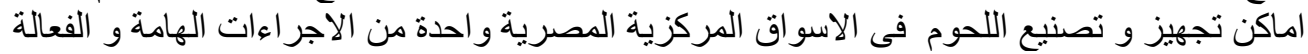
لمر اقبة المخاطر البيولوجية و التحكم بها كجز الهن من نظام الهاسب. 